\title{
Pengembangan Aplikasi Penilaian dan Rapor Terpadu Kurikulum 2013 Untuk Sekolah Dasar
}

\author{
Ida Bagus Purnandita ${ }^{1 *}$, Gede Aditra Pradnyana², P Wayan Arta Suyasa ${ }^{3}$ iD \\ ${ }^{123}$ Jurusan Teknik Informatika Universitas Pendidikan Ganesha, Bali, Indonesia \\ *Corresponding author: purnandita90@gmail.com
}

\begin{abstract}
Guru kurang menguasai aplikasi penilaian siswa yang dapat diakses melalui komputer sehingga menyebabkan guru kesulitan dalam melakukan proses penilaian. Tujuan penelitian ini adalah untuk mengembangkan aplikasi penilaian dan rapot terpadu kurikulum 2013 untuk sekolah dasar. Jenis penelitian ini adalah penelitian pengembangan. Model yang digunakan dalam mengembangkan media adalah model waterfall yang terdiri dari lima tahapan yaitu Requirements definitions, system and software design, implementation and unit testing, intergration and system testing, operation and maintenance. Teknik yang digunakan dalam mengumpulan data yaitu teknik wawancara, teknik observasi ataupun teknik angket/kuisioner. Teknik analisis data yang digunakan pada penelitian ini yaitu analisis deskriptif kualitatif dan analisis deskriptif kuantitatif. Hasil penelitian yaitu hasil review ahli media pembelajaran mendapat nilai rata-rata 93.7, ahli isi materi mendapat nilai rata-rata 87.4, dan uji respon pengguna mendapat nilai rata-rata. Penilaian tersebut masuk kedalam katagori baik sehingga aplikasi Rapor Berbasis WEB dan Mobile layak diterapkan sebagai aplikasi rapor untuk menunjang efektfitas dan efisiensi belajar mengajar. Aplikasi Rapor Berbasis WEB dan Mobile mempermudah guru dalam proses penilaian siswa.
\end{abstract}

Keywords: model waterfall; aplikasi rapor.

$$
\begin{aligned}
& \text { History: } \\
& \text { Received: } 24 \text { August } 2020 \\
& \text { Revised: } 1 \text { September } 2020 \\
& \text { Accepted: } 26 \text { September } 2020 \\
& \text { Published: } 7 \text { October } 2020
\end{aligned}
$$

Publisher: Undiksha Press

Licensed: This work is licensed under

a Creative Commons Attribution 3.0 License

\section{Introduction}

Pendidikan lebih dari sekedar pengajaran dan dapat diartikan sebagai suatu proses transfer ilmu, transformasi nilai, dan pembentukan kepribadian dengan segala aspek yang dicakupnya. Pendidikan merupakan cara penataan yang terstruktur guna mendewasakan seseorang (Miskawati, 2019; Wirasasmita \& Hendriawan, 2020). Dengan proses semacam ini suatu bangsa atau negara dapat mewariskan nilai-nilai keagamaan, kebudayaan, pemikiran dan keahlian kepada generasi berikutnya, sehingga mereka betul-betul siap menyongsong masa depan kehidupan bangsa dan negara yang lebih cerah (Nurkholis, 2013). Pendidikan juga merupakan kegiatan yang kompleks, dan meliputi berbagai komponen yang berkaitan erat satu sama lain. Oleh sebab itu, apabila pendidikan ingin dilaksanakan secara terencana dan teratur, maka berbagai faktor yang terlibat dalam pendidikan harus dipahami terlebih dahulu. Berbagai komponen dalam sistem pendidikan, baik secara mikro maupun dalam kajian makro perlu dikenali secara mendalam sehingga komponen-komponen tersebut dapat difungsikan dan dikembangkan guna mengoptimalkan garapan pendidikan tersebut ke arah pencapaian tujuan pendidikan yang ditetapkan (Sutrisno, 2016; Wuryandani, Sapriya, \& Budimansyah, 2014). Pendidikan menjadi bagian yang penting dalam perkembangan sebuah negara, karena akan menjadi dasar dalam membangun negara seperti Indonesia. Pemerintah 
terus berusaha memperbaiki kualitas sumber daya manusia di Indonesia, salah satunya melalui bidang pendidikan. Berbagai dukungan pelayanan dalam bidang pendidikan terus diupgrage menyesuikan dengan perkembangan ilmu pengetahuan dan teknologi. Hal tersebut dilakukan agar dapat memajukan pendidikan yang akan berdampak pada kualitas sumber daya manusia.

Permasalahan yang terjadi saat ini adalah guru kurang mampu menggunakan komputer. Penelitian yang dilakukan oleh Sahelatua, Vitoria, \& Mislinawati (2018) yang menyatakan bahwa guru masih mengalami kendala dalam mengoperasikan IT hal tersebut dikarenakan kurangnya pengetahuan guru tentang media IT. Permasalahan ini juga ditemukan pada salah satu sekolah dasar. Berdasarkan hasil observasi dan wawancara yang dilakukan di Sekolah Dasar Negeri No 18 Sesestan, didapatkan bahwa telah terdapat aplikasi rapor yang dibuat oleh Dinas Pendidikan Kota Denpasar diharapkan dapat menjadi sebuah terobosan baru dalam hal inovasi pelayanan publik untuk meningkatkan kualitas pelayanan serta mampu memudahkan guru untuk memberikan penilaian ke siswanya. Jika penilaian ini masih dikerjakan secara manual oleh para guru, dikhawatirkan nantinya akan dapat menghambat proses penilaian setiap siswa. Tetapi guru masih mengalami kendala dalam menggunakan aplikasi ini karena belum paham mengenai cara kerja aplikasi ini. Aplikasi yang digunakan adalah aplikasi pengolah angka yaitu Microsoft Excel. Aplikasi tersebut di dapat dari pusat dan hanya dapat digunakan melalui laptop atau komputer. Aplikasi rapor tersebut sudah sangat baik bagi guru yang sudah terbiasa menggunakan laptop atau komputer, namun untuk guru yang belum terlalu menguasai komputer aplikasi tersebut membuat guru menjadi kesulitan dalam melakukan proses penilaan, hal ini menjadikan salah satu kendala guru dalam proses penilaian siswa menggunakan kurikulum 2013. Berdasarkan wawancara yang dihasilkan oleh beberapa guru diperoleh informasi bahwa aplikasi tersebut sangat membantu dalam proses penilaian, selain itu beliau juga menyatakan bahwa belum pernah menggunakan aplikasi lain, hanya aplikasi yang diberikan oleh pemerintah, dari hasil observasi kendala yang dialami oleh guru yang menggunakan aplikasi tersebut adalah harus menggunakan laptop yang selalu dibawa ketika ingin memasukan nilai siswa. Terkadang guru juga bingung pada proses penilaian kepada siswa dikarenakan tidak adanya deskripsi penilaian untuk KI1 dan KI2 pada aplikasi tersebut, hal ini membuat guru kesulitan dalam memberikan nilai menggunakan aplikasi tersebut.

Guru biasanya memasukan nilai di akhir semester karena untuk membawa laptop setiap hari terlalu rumit karena membawa laptop terlalu berat, baterai laptop yang cepat habis dan terkadang catu daya di sekolah rusak, biasanya guru mencatat nilai siswa dengan buku daftar nilai yang sesuai aplikasi. Guru juga merasa kesulitan dalam memasukan nilai diakhir karena harus memasukan nilai siswa yang banyak, karena guru jarang memasukan nilai siswa pada apikasi saat proses belajar mengajar dan lebih memilih memasukan nilai diakhir sehingga pada waktu guru memasukan nilai siswa diakhir menjadi tidak optimal karena terbatas oleh waktu. Guru sudah menggunakan smartphone, tetapi guru jarang menggunakan laptop atau komputer. Hal ini juga dibenarkan oleh kepala sekolah yang menyatakan hampir semua guru sudah menggunakan smartphone android dikarenakan membawa smartphone lebih mudah, ringan dan juga baterai lebih tahan lama dibandingkan dengan membawa laptop, para guru juga sering membuka browser pada smartphone, para guru juga sering menggunkan smartphone untuk membuka website seperti Sistem Informasi Manajemen Program Pengembangan Keprofesian Berkelanjutan (SIM PKB). Dari hasil wawancara aplikasi tersebut juga hanya bisa digunakan untuk satu kelas dan satu semester, hal tersebut tentu menjadi kelemahan untuk aplikasi tersebut dikarenakan setiap pergantian semester para guru harus memasukan ulang data-data siswa karena setiap semester berbeda KD.

Kurikulum adalah seperangkat rencana dan pengaturan mengenai isi dan bahan pelajaran serta cara yang digunakan sebagai pedoman penyelenggaraan kegiatan 
pembelajaran untuk mencapai tujuan pendidikan tertentu (Nasihin, 2016; Rahmawati, 2018). Perubahan kurikulum juga merupakan akibat dari perkembangan masyarakat (Mulyadin, 2016; Sofyan, 2016). Dalam kurikulum 2013 sendiri mengharuskan para guru untuk merincikan lebih detail terkait dengan keempat aspek penilaian mulai dari aspek KI1 tentang aspek spiritual, KI2 tentang aspek sosial, KI3 tentang pengetahuan hingga KI4 tentang ketrampilan (Hasanah, Nurjaya, \& Astika, 2017; Oviana, 2015). Dengan perkembangan teknologi penerapan Kurikulum 2013 sangat membantu guru dalam penilaian siswa untuk menyusun rapor. Hal ini terlihat dari penilaian Kurikulum 2013 yang begitu kompleks sehingga mengharuskan guru menggunakan aplikasi rapor untuk mempermudah guru menghitung nilai akhir siswa. Kota Denpasar hadir dengan berbagai strategi untuk meningkatkan kualitas pelayanan khususnya pada bidang pendidikan, salah satunya yaitu membuat aplikasi rapor untuk sekolah-sekolah yang menggunakan kurikulum 2013. Komputer merupakan kebutuhan yang sangat penting bagi dunia pendidikan, seluruh guru diwajibkan untuk bisa menguasai komputer yang berguna untuk penyelesaian perangkat pembelajaran,administrasi guru, media (Khairil \& Ginta, 2012; Soewarno, Hasmiana, \& Faiza, 2016).

Tujuan penelitian ini adalah untuk mengembangkan aplikasi penilaian dan rapot terpada kurikulum 2013 untuk sekolah dasar. Penelitian ini memiliki perbedaan dengan penelitian sebelumnya yaitu penelitian ini mengembangkan aplikasi penilaian dan rapot terpadu dengan kurikulum 2013 yang dapat diakses melalui gadget. Aplikasi penilaian dan rapot terpadu dengan kurikulum 2013 diharapkan akan memudahkan guru dalam menginput nilai dengan tepat dan cepat. Fitur-fitur yang akan terdapat dalam aplikasi rapor Sekolah Dasar Negeri 18 Sesetan diantaranya seperti: (1) Aplikasi rapor online yang dapat terintegrasi oleh handphone sehingga guru tidak kesulitan membawa laptop kesekolah, ketika menggunakan handphone yang terkoneksi internet guru dapat memasukan nilai siswa ketika proses pembelajaran berlangsung, (2) Pada aplikasi tersebut juga akan disediakan deskripsi KI 1 dan KI 2 hal ini tentu mempermudah guru dalam proses penilaian siswa, (3) Tersedianya profil sekolah dan guru, (4) Aplikasi tersebut juga sudah otomatis jika kenaikan kelas sehingga guru tidak perlu memasukan ulang data siswa pada aplikasi, (5) Orang tua siswa dapat melihat perkembangan anaknya.

\section{Materials and Methods}

Pengembangan Aplikasi Rapor ini dikembangkan dengan menggunakan metode System Development Life Cycle (SDLC). Model yang digunakan dalam penelitian ini adalah model Waterfall. Model waterfall atau air terjun, atau yang kadang dinamakan siklus hidup klasik adalah pendekatan pengembangan perangkat lunak yang sistematis dan berurutan (sequential linier), yang dimulai dengan spesifikasi kebutuhan pengguna dan berlanjut melalui tahapan Analisa Kebutuhan(Requirements analysis and definition), Desain Sistem (System and software design), Implementasi (Implementation and unit testing), Integrasi dan Pengujian (Integration and system testing), Pemeliharaan(Operation and maintenance) pengujian yang diakhiri dengan dukungan berkelanjutan pada perangkat lunak lengkap yang dihasilkan. Model penelitian Waterfall memiliki beberapa tahapan yang harus dilaksanakan. Adapun fase - fase atau tahapan/prosedur dari model waterfall ini adalah sebagai berikut. 


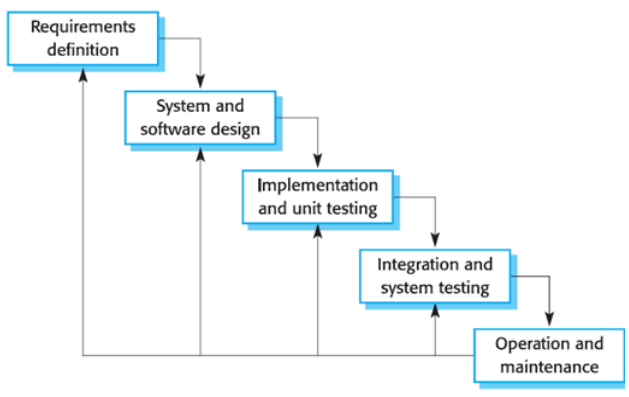

Gambar 1. Tahapan Model Waterfall

Tahap analisis kebutuhan ini merupakan tahap awal dimana peneliti melakukan proses analisa kebutuhan sistem, seperti pengumpulan data sebagai bahan pengembangan sistem. Pengumpulan data dapat dilakukan dengan teknik wawancara, teknik observasi ataupun teknik angket/kuisioner. Pada tahap ini peneliti melakukan pencarian informasi dengan observasi, wawancara dan angket/kuisioner di lingkungan Sekolah Dasar Negeri 18 Sesetan. Dari hasil pengumpulan informasi berupa analisis perangkat keras dan perangkat lunak yang dibutuhkan untuk membuat sistem. Teknik analisis data yang digunakan pada penelitian ini yaitu analisis deskriptif kualitatif dan analisis deskriptif kuantitatif.

\section{Results and Discussion}

Perangkat lunak pengembangan lunak pengembangan aplikasi rapor terpadu berbasis web dan mobile pada SDN 18 Sesetan ini dikembangkan pada lingkungan perangkat keras komputer (laptop) yang memiliki spesifikasi sebagai berikut. a) Monitor 13 inchi, b) Memori 4 GB SDRAM dan harddisk 256 GB, c) Processor intel core i5. Pengembangan aplikasi rapor terpadu berbasis web dan mobile pada SDN 18 Sesetan menggunakan model arsitektur client server. Dengan menggunakan arsitektur client server, masing-masing client atau pengguna aplikasi rapor dapat melakukan permintaan data atau informasi pada server. Alamat domain yang digunakan dalam implementasi aplikasi rapor terpadu berbasis web dan mobile pada SDN 18 Sesetan berada pada domain sdn18sesetan.com

Berdasarkan rancangan struktur data yang telah dibuat, dapat diimplementasikan struktur data pada perangkat lunak pengembangan aplikasi rapor terpadu berbasis web dan mobile pada SDN 18 Sesetan terdapat 22 tabel yang diimplementasikan. Adapun tabel-tabel yang telah diimplementasikan dipaparkan pada gambar 2 .

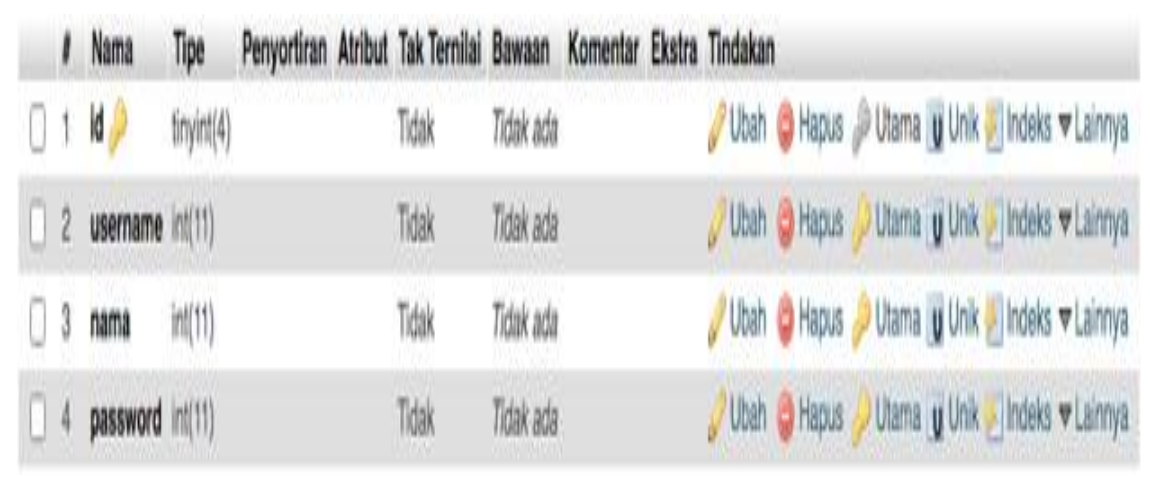

Gambar 2. Tabel Admin 


\begin{tabular}{|c|c|c|c|c|c|c|c|c|}
\hline " & 7 Nama & Tipe & Penyortiran & Atribut & $\begin{array}{l}\text { Tak } \\
\text { Ternilai }\end{array}$ & Bawaan & Komentar Ekstra & Tindakan \\
\hline D 1 & 1 id_nip & varchar(20) & lafint_swedish_ci & & Tidak & Tidak ada & & 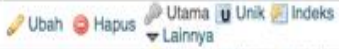 \\
\hline (1) 2 & 2 nama & varchar(255) & lasin1_swedish_ci & & Tidak & Tidak ada & & 2 Ubah $\theta$ Hapus $\nabla$ Lainna $u$ Unik Elindeks \\
\hline 03 & 3 tempat Jahir & varchar(256) & Iaini__swedish_ei & & Tidak & Tidak ads & & 2 Ubah $\theta$ Hapus $\rightarrow$ Lainna U Unik E Indeks \\
\hline D 4 & tanggal lahir & date & & & Tidak & Tidak ada & & 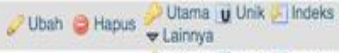 \\
\hline D 5 & $5 \mid k$ & enum(L', 'P) & latin1_swedish_ci & & Tidak & Tidak ads & & 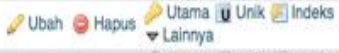 \\
\hline 06 & alamat & text & latint_swedish_ci & & ndaḱ & Tidak ada & & 2 Ubah $\theta$ Hapus Utama U Unik EI Indeks \\
\hline ㄱ. 7 & agama & varchar(255) & latini_swedish_ci & & Tidak & Tidak ada & & $\begin{array}{l}\text { 2Ubah } 9 \text { Hapus Utama U Unik ¿ Indeks } \\
\nabla \text { Laintya }\end{array}$ \\
\hline D. 8 & id jabatan & int $(20)$ & & & Tidak & Tidak ada & & $\begin{array}{l}2 \text { Ubah } \theta \text { Hapus Utama U Unik E Indeks } \\
\nabla \text { Lainnya }\end{array}$ \\
\hline 09 & status guru & varchar(255) & lasin1_swedish_ci & & Tidak & Tidak ada & & 2 Ubah $\theta$ Hapus Utama U Unik E Indeks \\
\hline
\end{tabular}

\section{Gambar 3. Tabel Guru}

Implementasi layar antarmuka perangkat lunak merupakan proses pembuatan layar antarmuka dari interaksi pengguna sistem dengan komputer. Interaksi ini dapat berupa proses menambah data, mengubah data, menghapus data dan proses menjalankan sistem. Disajikan pada gambar 4, 5, 6, 7, 8, 9, 10, dan 11 .

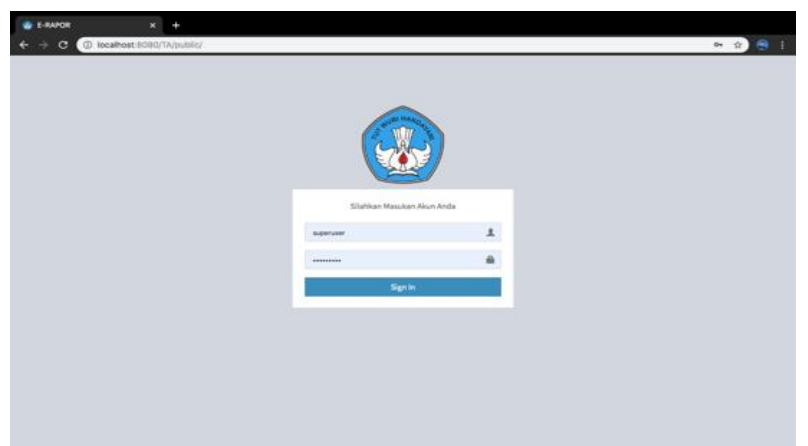

Gambar 4. Implementasi Antarmuka Website Login

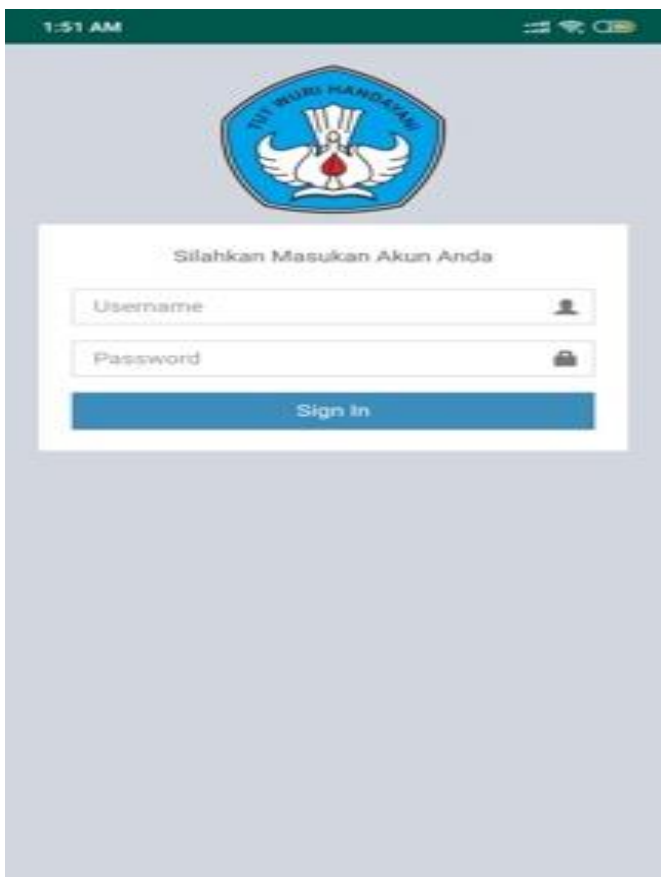

Gambar 5. Implementasi Antarmuka Mobile Login 


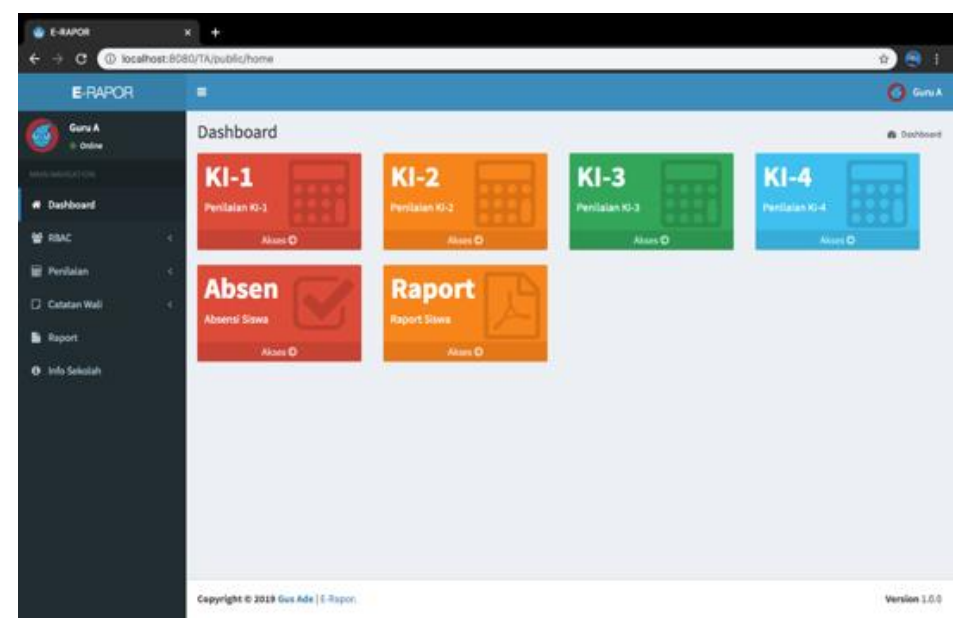

Gambar 6. Implementasi Antarmuka Website Halaman Awal Wali
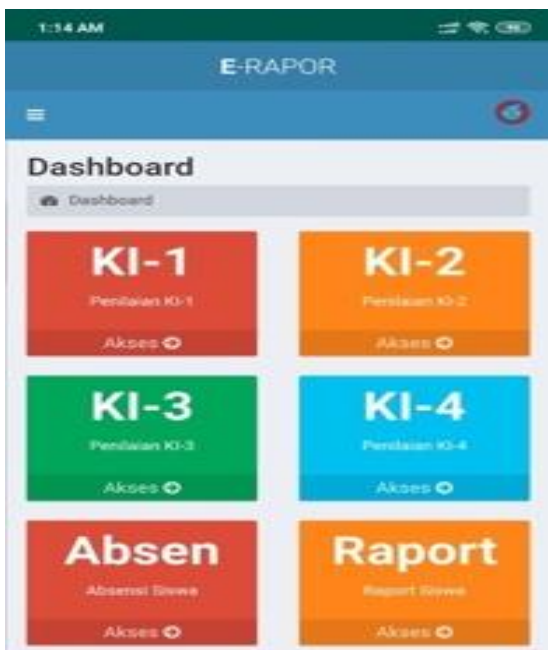

Raport

$\cos 2 \sin 10$

Copyright 02019 Gus Ade I E-Fapor

Gambar 7. Implementasi Antarmuka mobile Halaman Awal Wali

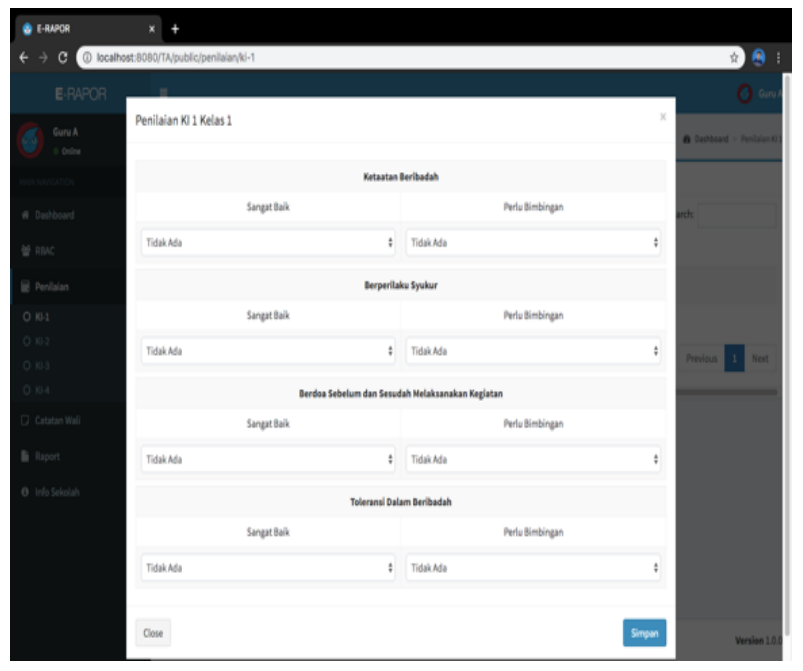

Gambar 8. Implementasi Antarmuka Website Tambah Penilaian KI-1 


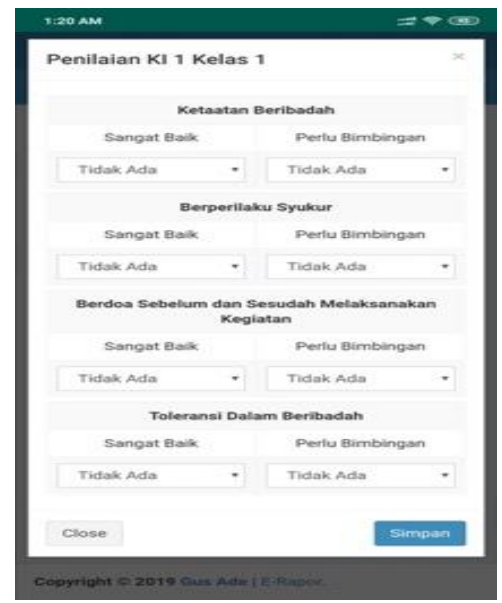

Gambar 9. Implementasi Antarmuka Mobile Tambah Penilaian KI-1

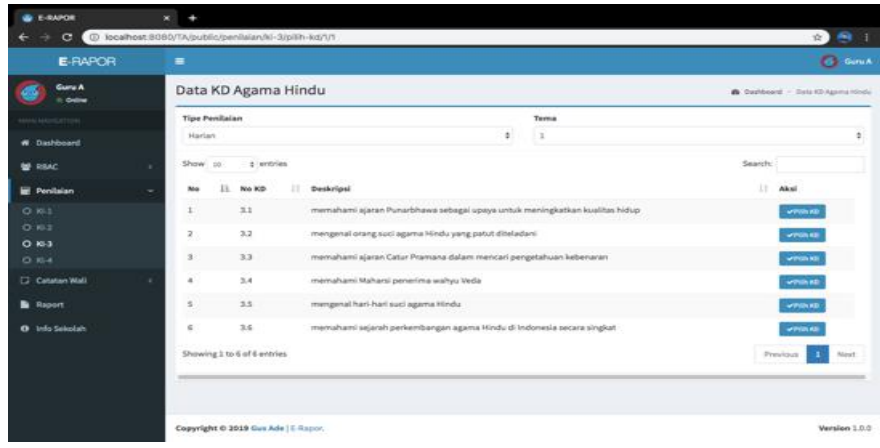

Gambar 10. Implementasi Antarmuka Website Tambah Penilaian KI-3

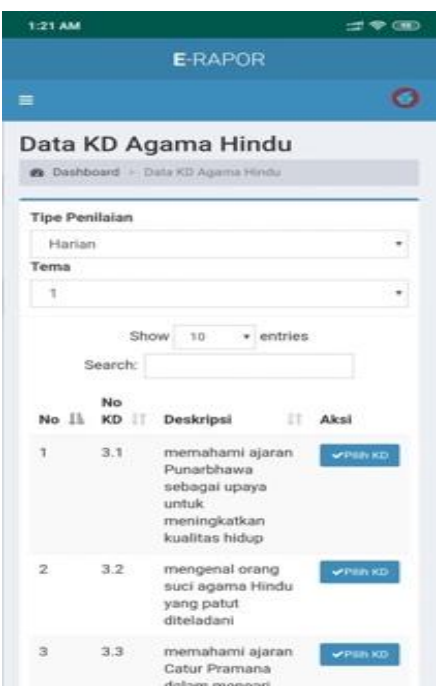

Gambar 11. Implementasi Antarmuka Mobile Tambah Penilaian KI-3

Setelah media berhasil dikembangkan selanjutnya dilakukan pengujian perangkat lunak aplikasi rapor berbasis web. Pengujian perangkat lunak aplikasi rapor berbasis web dan mobile pada SDN 18 Sesetan dilakukan dengan beberapa tahapan, yaitu whitebox testing, blackbox testing, Respon pengguna dengan menggunakan pengujian System Usability Scale (SUS) yaitu 1) Hasil pengujian fungsional (blackbox testing) mulai dari saat pertama kali sistem dijalankan sampai dengan selesai dan keluar, aplikasi rapor berbasisi web dan mobile 
SDN 18 Sesetan berfungsi dengan baik. Semua fitur pada sistem ditampilkan sesuai dengan yang diharapkan, 2) Pengujian struktural (whitebox testing) dilakukan terhadap source code dengan tujuan menguji alur proses dan logika yang ada. Dari hasil pengujian tersebut dapat disimpulkan bahwa semua fungsi code yang terdapat di aplikasi rapor berbasisi web dan mobile SDN 18 Sesetan berjalan dengan baik dan benar. Selanjutnya dilakukan uji media menurut para ahli media, ahli isi, dan uji respon pengguna. Pengujian ini dilakukan dengan melibatkan dua ahli media. Pengujian ini dilakukan bertujuan untuk menguji interface sistem. Berdasarkan hasil penilaian dari ahli media didapatkan nilai rata-rata 93,7.

Setelah dilakukan uji media, kemudian dilanjutkan dengan uji isi oleh ahli isi. Pengujian ini dilakukan dengan melibatkan dua ahli. Pengujian ini dilakukan bertujuan untuk menguji hasil perhitungan nilai siswa. Apakah sistem dapat sesuai menampilkan hasil nilai siswa pada aplikasi yang digunankan guru terhadap sistem yang dikembangkan. Pengujian ini melibatkan 2 guru yang sudah sering menggunakan aplikasi rapor yang sudah ada pada sekolah. Berdasarkan hasil penilaian dari ahli isi didapatkan nilai rata-rata 87,4.

Selanjutnya dilakukan uji respon pengguna. Pengujian ini menggunakan System Usability Scale (SUS) bertujuan untuk mengetahui kebermanfaatn sistem yang dikembangkan. Pengujian dilakukan dengan melibatkan pengguna yang berinteraksi dengan sistem ini. Adapun pengguna yang dilibatkan adalah 1 Kepala Sekolah SDN 18 Sesetan, 1 WKS/ Staff Kurikulum, 2 Wali Kelas, 2 guru dan 4 orang tua siswa. Berikut ini ikhtisar tentang bagaimana skor harus diukur : Grade A: dengan skor lebih besar atau sama dengan 80,3, Grade B: dengan skor lebih besar atau sama dengan 74 dan lebih kecil dari 80,3, Grade C: dengan skor lebih besar atau sama dengan 64 dan lebih kecil dari 74, Grade D: dengan skor lebih besar atau sama dengan 51 dan lebih kecil dari 64. Hasil penilaian disajikan pada tabel

Tabel 1. Hasil Pengujian System Usability Scale (SUS)

\begin{tabular}{llll}
\hline No & Responden & Skor & Nilai \\
\hline 1 & X1 & 34 & 85 \\
2 & X2 & 32 & 80 \\
3 & X3 & 36 & 90 \\
4 & X4 & 33 & 82.5 \\
5 & X5 & 32 & 80 \\
6 & X6 & 30 & 75 \\
7 & X7 & 29 & 72.5 \\
8 & X8 & 33 & 82.5 \\
9 & X9 & 30 & 75 \\
10 & X10 & 31 & 77.5 \\
\hline Rata-Rata & & $\mathbf{8 0}$ \\
\hline
\end{tabular}

Berdasarkan hasil penilaian uji respon penguna didapatkan nilai rata-rata 80 sehingga masuk kedalam kualifikasi baik (B). Pelaksanaan pengujian perangkat lunak berlangsung dengan baik dan lancar. Berdasarkan hasil pengujian blackbox testing (pengujian fungsionalitas) diperoleh bahwa semua proses yang dilakukan oleh user mampu berjalan dengan baik dan menghasilkan inputan yang sesuai dengan spesifikasi. Kemudian pengujian whitebox testing (pengujian struktural) diperoleh bahwa implementasi algortima telah berhasil sehingga mendapatkan hasil yang sesuai. Selanjutnya berdasarkan pengujian respon pengguna atau pengujian lapangan diproleh hasil baik atau sebesar $80 \%$ yang mana menyatakan bahwa sistem telah memenuhi kebutuhan dari user. Pada pengujian kelayakan sistem hasil yang diperoleh bahwa Aplikasi Rapor Berbasis WEB dan Mobile SDN 18 
Sesetan layak diterapkan sebagai aplikasi rapor untuk menunjang efektifitas dan efisiensi belajar mengajar di SDN 18 Sesetan. Hal tersebut disebabkan oleh beberapa faktor yaitu

Pertama, Aplikasi Rapor Berbasis WEB dan Mobile dikembangkan dengan cara yang sistematis sehingga efektif dan layak untuk digunakan. Aplikasi Rapor Berbasis Web dan Mobile pada SDN 18 Sesetan dalam perancangan dan pengembangannya menerapakan metode System Development Life Cycle (SDLC) dengan model waterfall. Ada pun tahapan penelitian dari metode tersebut adalah Analisa Kebutuhan (Requirements analysis and definition) peneliti melakukan pencarian informasi dengan observasi dan wawancara. Desain Sistem (System and software design) merupakan tahapan kedua dalam metode waterfall, terdapat beberapa bahasan yaitu batasan perancangan perangkat lunak, perancangan arsitektur perangkat lunak, perancangan struktur data perangkat lunak, dan perancangan antarmuka perangkat lunak. Integrasi dan Pengujian (Integration and system testing) pada tahap implementasi aplikasi rapor berbasis web dan mobile pada SDN 18 Sesetan dikembangkan dengan menggunakan framework laravel. Pengembangan aplikasi ini menggunakan arsitektur komputer client-server .

Kedua, Aplikasi Rapor Berbasis WEB dan Mobile yang dikembangkan memiliki beberapa fungsi sehingga efektif dan layak untuk digunakan. Pada web base beberapa fungsi yang diimplementasikan adalah fungsi pengelolaan data seperti membantu pengguna mengelola informasi terkait penilaian siswa, membantu pengelolaan nilai rapor, membantu pengguna mengelola data informasi guru, mengelola data informasi siswa, dan mengelola data informasi sekolah. Pada fitur-fitur yang terdapat dalam aplikasi rapor Sekolah Dasar Negeri 18 Sesetan seperti Aplikasi rapor online yang dapat terintegrasi oleh handphone sehingga guru tidak kesulitan membawa laptop kesekolah ketika menggunakan handphone yang terkoneksi internet guru dapat memasukan nilai siswa ketika proses pembelajaran berlangsung. Handphone dapat membantu dalam memperoleh informasi yang bermanfaat (Noviar, 2016; Sunismi, 2015). Pada aplikasi yang dikembakan juga disediakan deskripsi KI 1 dan KI 2 hal ini tentu mempermudah guru dalam proses penilaian siswa, tersedianya profil sekolah dan guru, aplikasi tersebut juga sudah otomatis jika pergantian semester guru tidak perlu memasukan ulang data siswa pada aplikasi, orang tua siswa dapat melihat perkembangan anaknya, hal ini dapat dilihat dari beberapa hasil pengujian yang dilakukan dapat dinyatakan bahwa tujuan penelitian sudah tercapai. Penelitian yang dilakukan oleh Sari \& Muhartini (2017) menyatakan bahwa penggunaan aplikasi Microsoft exel sangat membantu dalam proses penilaian secara tepat.

\section{Conclusion}

Berdasarkan hasil analisis data didapatkan pengujian ahli media, pengujian ahli isi dan pada pengujian respon pengguna menggunakan metode System Usability Scale (SUS) menyatakan bahwa semua kebutuhan dari pengguna telah terpenuhi. Dapat disimpulkan aplikasi rapor berbasis WEB dan Mobile layak diterapkan sebagai aplikasi rapor untuk menunjang efektifitas dan efisiensi belajar mengajar di SDN 18 Sesetan. Aplikasi rapor dengan dasar menggunakan web sebagai platform utama dan webview pada smartphone android yang memudahkan pengguna untuk mengakses aplikasi. Platform web dan webview pada android dalam sangat membantu untuk meningkatkan efisiensi waktu dalam mengolah nilai siswa.

\section{References}

Hasanah, Nurjaya, \& Astika. (2017). Pengintegrasian Sikap Spiritual dan Sikap Sosial dalam Pembelajaran Teks Ulasan Film/Drama dalam Pembelajaran Teks Ulasan Film/Drama di Kelas XI MIPA SMA Negeri 3 Singaraja. Jurnal Pendidikan Bahasa Dan Sastra Indonesia Undiksha, 7(2). https://doi.org/http://dx.doi.org/10.23887/jjpbs.v7i2.11579 
Khairil, \& Ginta. (2012). Implementasi Pengamanan Database Menggunakan MD5. Jurnal Media Infotama, 8(1). https://doi.org/https://doi.org/10.37676/jmi.v8i1.70.

Miskawati, M. (2019). Upaya Meningkatkan Kreativitas Anak Dalam Pembelajaran Seni Tari Melalui Strategi Belajar Sambil Bermain di TK Islam Sa'adatul Khidmah Tahun Pelajaran 2016/2017. Jurnal Ilmiah Dikdaya, 9(1), 45. https://doi.org/10.33087/dikdaya.v9i1.123

Mulyadin. (2016). Implementasi Kebijakan Pembelajaran Tematik Terpadu Kurikulum 2013 di SDN Kauman 1 Malang dan SD Muhammadiyah 1 Malang. Jurnal Pendidikan Edutama, 3(2), 31-48. https://doi.org/http://dx.doi.org/10.30734/jpe.v3i2.35.

Nasihin, S. (2016). Implementasi Kurikulum 2013 di MTs Yaqin 1 Kwang Rundun Kecamatan Jerowaru (Masalah dan Solusinya). Jurnal Studi Keislaman Dan Ilmu Pendidikan, 4(1), 56-86. https://doi.org/https://doi.org/10.36088/palapa.v4i1.8.

Noviar, D. (2016). Pengembangan Ensiklopedi Biologi Mobile Berbasis Android Materi Pokok Pteridophyta Dalam Rangka Implementasi Kurikulum 2013. Cakrawala Pendidikan, 35(2). Retrieved from https://journal.uny.ac.id/index.php/cp/article/view/8255/pdf.

Nurkholis. (2013). Pendidikan dalam Upaya Memajukan Teknologi. Jurnal Kependidikan, 1(24). https://doi.org/https://doi.org/10.24090/jk.v1i1.530

Oviana, W. (2015). Kemampuan Mahasiswa Mengintegrasikan Sikap Spiritual dan Sosial dalam Pembelajaran Berbasis Kurikulum 2013 (Kajian teoritis). Pionir Jurnal Pendidikan, 4(2). Retrieved from https://jurnal.arraniry.ac.id/index.php/Pionir/article/view/183/164\%0A

Rahmawati, A. (2018). Identifikasi Masalah yang Dihadapi Guru dalam Penerapan Kurikulum 2013. Indonesian Journal of Primary Education, 2(1), 114-123.

Sahelatua, Vitoria, \& Mislinawati. (2018). Kendala Guru Memanfaatkan Media IT Dalam Pembelajaran Di Sdn 1 Pagar Air Aceh Besar. Jurnal Pendidikan Guru Sekolah Dasar, 3(2). Retrieved from http://www.jim.unsyiah.ac.id/pgsd/article/view/8579.

Sari, \& Muhartini. (2017). Sistem Aplikasi Pengolahan Nilai Raport SDN Tanjung Anom 2 Kecamatan Tanjunganom Nganjuk. Jurnal Ilmiah Teknik Informatika, 11(1). https://doi.org/https://doi.org/10.35457/antivirus.v11i1.199.

Soewarno, Hasmiana, \& Faiza. (2016). Kendala-Kendala Yang Dihadapi Guru Dalam Memanfaatkan Media Berbasis Komputer Di SD Negeri 10 Banda Aceh. Jurnal Ilmiah Mahasiswa Prodi PGSD FKIP Unsyiah, 1(1). Retrieved from http://www.jurnal.unsyiah.ac.id/PEAR/article/view/7530\%0A

Sofyan. (2016). Pembelajaran Problem Based Learning dalam Implementasi Kurikulum 2013 di SMK. Jurnal Pendidikan Vokasi, 6(3), 260-271. https://doi.org/https://doi.org/10.21831/jpv.v6i3.11275

Sunismi. (2015). Developing Guided Discovery Learning Materials Using Mathematics Mobile Learning Application As An Alternative Media For The Students Calculus II. Cakrawala Pendidikan, 34(3), 334-346. Retrieved from https://journal.uny.ac.id/index.php/cp/article/view/7340/pdf.

Sutrisno. (2016). Berbagai Pendekatan Dalam Pendidikan Nilai Dan Pendidikan Kewarganegaraan. Jurnal Dimensi Pendidikan Dan Pembelajaran, 4(1). https://doi.org/http://dx.doi.org/10.24269/dpp.v4i1.56 
Wirasasmita, \& Hendriawan. (2020). Analisis Efisiensi Kinerja Pendidik terhadap Hasil Pembelajaran Pendidikan Jasmani pada Siswa Sekolah. Mimbar Pendidikan, 5(1), 7590. https://doi.org/https://doi.org/10.17509/mimbardik.v5i1.24152

Wuryandani, Sapriya, \& Budimansyah. (2014). Pendidikan Karakter Disiplin Di Sekolah Dasar. Cakrawala Pendidikan, 33(2), 286-295. Retrieved from https://journal.uny.ac.id/index.php/cp/article/view/2168/pdf. 